\title{
Drying-rewetting cycles alter carbon and nitrogen mineralization in litter-amended alpine wetland soil
}

\author{
Junqin Gao ${ }^{\mathrm{a}, *}$, Jin Feng ${ }^{\mathrm{a}}$, Xuewen Zhang ${ }^{\mathrm{a}}$, Fei-Hai Yu ${ }^{\mathrm{a}, *}$, Xingliang Xu ${ }^{\mathrm{b}}$, Yakov Kuzyakov ${ }^{\text {b,c,d }}$ \\ a School of Nature Conservation, Beijing Forestry University, Beijing 100083, China \\ ${ }^{\mathrm{b}}$ Key Laboratory of Ecosystem Network Observation and Modeling, Institute of Geographic Sciences and Natural Resources Research, Chinese Academy of Sciences, Beijing 100101, China \\ c Department of Soil Science of Temperate Ecosystems, University of Göttingen, Göttingen, Germany \\ d Department of Agricultural Soil Science, University of Göttingen, Göttingen, Germany
}

\section{A R T I C L E I N F O}

\section{Article history:}

Received 27 November 2015

Received in revised form 28 April 2016

Accepted 16 June 2016

Available online 22 June 2016

\section{Keywords:}

Alpine wetland

C mineralization

Drying-rewetting cycles

Litter addition

$\mathrm{N}$ mineralization

Soil organic C

\begin{abstract}
A B S T R A C T
Wetting-drying cycles can influence decomposition of litter and soil organic carbon (SOC) and their mineralization, but such effects have seldom been explored in alpine wetland soils. We conducted a 120-day incubation experiment with alpine wetland soils to which we added litter or not. These soil samples were assigned to two constant moisture treatments ( $60 \%$ or $100 \%$ soil water-holding capacity, WHC) or to a wetting-drying treatment that cycled between $60 \%$ and 100\% WHC. Drying-rewetting cycles significantly accelerated carbon (C) mineralization and nitrogen $(\mathrm{N})$ immobilization compared to soil under saturated soil moisture conditions. Litter addition greatly increased $\mathrm{C}$ mineralization and $\mathrm{N}$ immobilization, but the intensity of mineralization was regulated by soil moisture through microbial biomass. A significantly negative relationship between $\mathrm{C}$ and $\mathrm{N}$ mineralization became more pronounced when litter was added. Thus, drying-rewetting cycles can alter $\mathrm{C}$ and $\mathrm{N}$ mineralization, and this effect can strongly depend on litter in alpine wetlands. This indicates that future climate change could affect $C$ stocks in alpine wetland soil through altering moisture and litter production.
\end{abstract}

(c) 2016 Elsevier B.V. All rights reserved.

\section{Introduction}

The importance of wetlands for global carbon (C) cycling is highlighted by the very large amount of $C$ stored in wetland soils. This C storage corresponds to $20-30 \%$ of the terrestrial soil organic C (SOC, $2300 \mathrm{Pg}$ ) pool, although wetlands only cover $5-8 \%$ of the land surface (Mitsch and Gosselink, 2007; IPCC, 2013). The large amount of C accumulated in wetlands is mainly ascribed to slow SOC decomposition in anaerobic environments caused by waterlogging. This $\mathrm{C}$ can be released back to the atmosphere via increase in microbial decomposition caused by climate change, e.g., increased temperature and changed precipitation regime (Reichstein et al., 2013). Future climate change has been predicted to increase frequencies of extreme climate events, such as intense episodes of precipitation and prolonged droughts in many regions (IPCC, 2013; Reichstein et al., 2013). This could accelerate the dynamics of soil moisture change and drying-rewetting cycles, especially in wetlands (Seneviratne et al., 2010). During drying-rewetting cycles, litter and the surface soil in wetlands may shift between anaerobic and aerobic conditions, which may further affect microbial decomposition of litter and SOC (Moyano et al., 2013; Zhu and Cheng, 2013).

\footnotetext{
* Corresponding authors at: School of Nature Conservation, Beijing Forestry University, Qinghuadonglu 35, Haidian District, Beijing 100083, China.

E-mail addresses: gaojq@bjfu.edu.cn (J. Gao), feihaiyu@bjfu.edu.cn (F.-H. Yu).
}

The surface soil often dries gradually due to evapotranspiration and then rapidly rewets as a result of precipitation (Fierer and Schimel, 2002; Zhu and Cheng, 2013). The drying of the organic horizon in wetlands is faster and more intense than that of the mineral horizon due to the absence of capillary rise in the organic horizon. Furthermore, the $\mathrm{C}$ in the surface layer is not associated with soil minerals that can protect SOC from microbial decomposition. A rewetting event after a prolonged drought can increase microbial activity (Prieme and Christensen, 2001; Jarvis et al., 2007; Borken and Matzner, 2009) and thus $\mathrm{CO}_{2}$ emission from soil (Huxman et al., 2004; Rey et al., 2005; Borken and Matzner, 2009; Inglima et al., 2009; Moyano et al., 2013). Consequently, C and nitrogen $(\mathrm{N})$ mineralization are strongly accelerated (Borken and Matzner, 2009). At the same time, such changes in soil moisture increase litter-derived $\mathrm{C}$ incorporation into microbial biomass and litterderived $\mathrm{CO}_{2}$ emissions (Benesch et al., 2015). The contribution of litter-derived $\mathrm{CO}_{2}$ during the wet period is approximately three-fold higher than during the dry period (Ataka et al., 2014). Increased soil moisture accelerates SOC decomposition caused by exudates or labile C inputs through litter decomposition (Dijkstra and Cheng, 2007; Zhu and Cheng, 2013). Therefore, drying-rewetting cycles influence available nutrients and microbial activities mainly by altering soil moisture (Jarvis et al., 2007; Bengtson et al., 2012; Bernal and Mitsch, 2013). Additionally, drying-rewetting cycles can modify SOC decomposition by breaking up aggregates and releasing inaccessible $\mathrm{C}$, depending on soil 
drying intensity (Zhu and Cheng, 2013). Generally, moderate hydrophobicity can improve aggregate stability, protecting SOM from decomposition. Drying-rewetting cycles may decrease the hydrophobicity and activate SOC decomposition (Borken and Matzner, 2009), but it remains unclear how drying-rewetting cycles affect litter decomposition and SOC mineralization in alpine wetlands.

The Tibetan Plateau contains a vast area of wetlands (roughly $5.1 \times 10^{3} \mathrm{~km}^{2}$ ) (Xing et al., 2009). The Zoigê Wetlands, located in the northeastern part of the Tibetan Plateau, represent the largest peatland in China (Zhang et al., 2011), which contains about $0.5 \mathrm{Pg}$ C, roughly $88 \%$ of the C stocks in the Tibetan wetlands (Xing et al., 2009). These alpine wetlands are predicted to undergo more frequent and intense dryingrewetting cycles due to climate change (Huntington, 2006; IPCC, 2013; Liao, 2013). To clarify effects of drying-rewetting cycles caused by climate change, we conducted a 120-day incubation experiment with litter additions to soils collected in the Zoigê alpine wetlands. We hypothesized (1) that drying-rewetting cycles greatly increase litter and SOC decomposition compared to saturated moisture conditions, and (2) that litter reduces $\mathrm{N}$ mineralization through increase in microbial $\mathrm{N}$ immobilization, and the this process can be intensified by drying-rewetting cycles.

\section{Materials and methods}

\subsection{Research site and soil/litter collection}

Both soil and litter were collected from a wetland located at the Zoigê Natural Reserve $\left(33^{\circ} 35^{\prime} \mathrm{N}, 102^{\circ} 57^{\prime} \mathrm{E}, 3440 \mathrm{~m}\right.$ a.s.l.) on the eastern Tibetan Plateau, China. The wetland is characterized by a subalpine, continental and monsoonal climate, with mean annual temperature of $0.6^{\circ} \mathrm{C}$ and mean annual precipitation from 500 to $657 \mathrm{~mm}$ (Ding et al., 2004; Yu et al., 2010). In this wetland, total vegetation cover is over 90\%. The dominant species are Carex muliensis Hand-Mazz. and Carex lasiocarpa Ehrh., which contribute $>60 \%$ of total vegetation cover. Other common species include Potentilla anserina L., Kobresia tibetica Maxim., and Caltha palustris L. The soil is classified as humus marsh soil (Chai et al., 1965), corresponding to histosols based on FAO soil taxonomy (WRB, 2014).

On the soil surface, there was a litter layer $<2 \mathrm{~cm}$ thick that was little decomposed. We collected the litter of the two dominant species (C. muliensis and C. lasiocarpa) from five randomly selected sites at least $20 \mathrm{~m}$ apart. The litter was brought to a laboratory, washed, air dried, and cut to about $2 \mathrm{~cm}$ long. Litter $\mathrm{N}$ content was $18.2 \pm$ $0.9 \mathrm{~g} \mathrm{~kg}^{-1}$ (mean $\pm \mathrm{SE}, \mathrm{n}=5$ ), organic $C$ content was $454 \pm$ $6 \mathrm{~g} \mathrm{~kg}^{-1}$ and $\mathrm{C}: \mathrm{N}$ ratio was $25.0 \pm 2.0$. In the Zoigê Wetlands, the surface soil, including the litter layer, experiences frequent drying-rewetting cycles (Liao, 2013).

We collected the soil from 0 to $10 \mathrm{~cm}$ depth in the $\mathrm{H}$ horizon at the same sites after litter removal. The soil was immediately brought to the laboratory and passed through a $4-\mathrm{mm}$ sieve. The soil contained $70.4 \pm 15.9 \mathrm{~g} \mathrm{~kg}^{-1}$ total organic C, $293 \pm 27 \mathrm{mg} \mathrm{kg}^{-1}$ dissolved organic carbon (DOC), $25.7 \pm 6.9 \mathrm{mg} \mathrm{kg}^{-1}$ microbial biomass carbon (MBC) and $5.6 \pm 0.6 \mathrm{~g} \mathrm{~kg}^{-1}$ total $\mathrm{N}$. The soil had a C:N ratio of $12.6 \pm 1.3, \mathrm{pH}$ of $6.9 \pm 0.1$ and a bulk density of $0.3 \pm 0.03 \mathrm{~g} \mathrm{~cm}^{-3}$, and contained $9.8 \%$ clay, $80.9 \%$ silt, and $9.3 \%$ sand.

\subsection{Incubation experiment}

The sieved soil was homogenized and randomly separated into two portions. In one portion, moisture was adjusted to $60 \%$ of the soil waterholding capacity (WHC), and in the other it was adjusted to $100 \%$ of the soil WHC. The two portions were then pre-incubated for five days at room temperature (about $20^{\circ} \mathrm{C}$ ) in the dark before litter addition. We chose $60 \%$ WHC as the dry treatment because it favors soil microbes and is common in the Zoige Wetlands.
The incubation experiment used a factorial design with three soil water treatments (dry, wet, and drying-rewetting cycle) crossed with two litter treatments (with and without litter addition), making in total six treatments. In the dry treatment, water content in the soil was kept to $60 \%$ WHC during the whole experiment, and in the wet treatment water content was maintained at 100\% WHC. In the dryingrewetting cycle treatment, the soil was subjected to 12 cycles of wetting and drying regimes during the experimental period (Fig. 1). Within each cycle, soil water content was first maintained at 100\% WHC for two days and then gradually decreased from $100 \%$ to $60 \%$ WHC during eight days of drying in a closed volume of air with $20 \mathrm{~g} \mathrm{CaCl}_{2}$. The amount of $\mathrm{CaCl}_{2}$ was determined by the pre-incubation experiment.

We placed the pre-incubated soil (corresponding to $60 \mathrm{~g}$ dry weight) in $600-\mathrm{ml}$ jars. One third of the jars were filled with the soil preincubated at $60 \% \mathrm{WHC}$, and used for the dry treatment. Another $1 / 3$ were filled with the soil pre-incubated at $100 \%$ WHC, and used for the wet treatment. The remaining $1 / 3$ were also filled with the soil preincubated at $100 \% \mathrm{WHC}$, but used for the drying-rewetting treatment. For each of the three water treatments, half of the jars were randomly selected for addition of air-dried litter pieces corresponding to $2 \mathrm{~g}$ dry weight.

The experiment started on 28 July 2012, and the soil in the jars was incubated in dark for up to $120 \mathrm{~d}$ at $20^{\circ} \mathrm{C}$. At the start of the experiment, four additional jars with a beaker containing $10 \mathrm{ml}$ distilled $\mathrm{H}_{2} \mathrm{O}$ and a beaker containing $10 \mathrm{ml} 0.1 \mathrm{M} \mathrm{NaOH}$ were sealed, and served as controls to account for $\mathrm{CO}_{2}$ trapped from the air. In each treatment, jars were each provided with a vial containing $10 \mathrm{ml} 0.1 \mathrm{M} \mathrm{NaOH}$ to trap $\mathrm{CO}_{2}$ from respiration and a vial containing $\mathrm{CaCl}_{2}$ to absorb water vapor, and were also sealed. $\mathrm{NaOH}$ solution and $\mathrm{CaCl}_{2}$ were replaced periodically, well before saturation occurred (Fig. 1). In this way, $\mathrm{CO}_{2}$ released from the soil was measured at each dry and wet period.

\subsection{Chemical analyses}

$\mathrm{C}$ and $\mathrm{N}$ contents of soil and litter were analyzed with a stable isotope-ratio mass spectrometer (MAT-253,Thermo Fisher, USA), and DOC in fresh soil was determined with a TOC analyzer (Analytikjena Corp., Germany). Soil pH was measured using a digital pH meter. Soil bulk density was estimated by dividing the weight of the dried soil by the volume of the soil (Blake and Hartge, 1986). The particle fractions of the soil samples were analyzed with a Longbench Mastersizer 2000 (Malvern Instruments, Malvern, England). Microbial biomass C (MBC) and $\mathrm{N}(\mathrm{MBN})$ were determined using a chloroform fumigation extraction method (Brookes et al., 1985; Wu et al., 1990).

To quantify $\mathrm{CO}_{2}$ emissions from the soil, $\mathrm{CO}_{2}$ trapped in the $\mathrm{NaOH}$ solution was analyzed by titrating $\mathrm{NaOH}$ against $0.1 \mathrm{M} \mathrm{HCl}$ (He et al., 2014). Total $\mathrm{CO}_{2}$ emission ( $\mathrm{C}$ mineralization) was calculated by aggregating $\mathrm{CO}_{2}$ emissions for the complete duration of the incubation. Soil

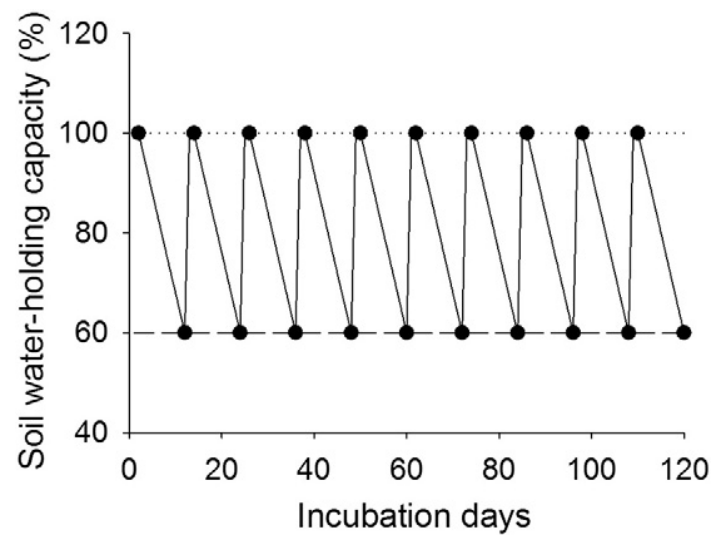

Fig. 1. Soil moisture content during the entire experimental period. $\mathrm{CO}_{2}$ trapping was conducted (indicated as black dots) at each drying-rewetting cycle. 
Table 1

Effects of water treatment (dry, wet and wet-dry cycle) and litter addition on cumulative $\mathrm{CO}_{2}$ emission ( $\mathrm{C}$ mineralization), net $\mathrm{N}$ mineralization, microbial biomass $\mathrm{C}(\mathrm{MBC})$, and microbial biomass $\mathrm{N}(\mathrm{MBN})$.

\begin{tabular}{|c|c|c|c|c|c|c|c|c|}
\hline \multirow[t]{2}{*}{ Effect } & \multicolumn{2}{|c|}{$\mathrm{CO}_{2}$ emission } & \multicolumn{2}{|c|}{$\mathrm{N}$ mineralization } & \multicolumn{2}{|l|}{$\mathrm{MBC}$} & \multicolumn{2}{|l|}{$\mathrm{MBN}$} \\
\hline & $F$ & $P$ & $F$ & $P$ & $F$ & $P$ & $F$ & $P$ \\
\hline Water (W) & 39.4 & $<0.001$ & 55.9 & $<0.001$ & 5.7 & 0.012 & 30.3 & $<0.001$ \\
\hline Litter (L) & 1414.0 & $<0.001$ & 86.1 & $<0.001$ & 115.1 & $<0.001$ & 123.1 & $<0.001$ \\
\hline $\mathrm{W} \times \mathrm{L}$ & 35.4 & $<0.001$ & 28.6 & $<0.001$ & 1.9 & 0.182 & 11.3 & 0.001 \\
\hline
\end{tabular}

Degrees of freedom are 2,18 for the effects of water treatment and of water treatment $x$ litter addition, and 1,18 for the effect of litter addition.

$P$ values less than 0.05 are in bold.

$\mathrm{NO}_{3}^{-}-\mathrm{N}$ and $\mathrm{NH}_{4}^{+}-\mathrm{N}$ were determined with a Seal Auto Analyzer 3 (Bran LUEBBE, Germany) in $0.05 \mathrm{M} \mathrm{K}_{2} \mathrm{SO}_{4}$ extracts (He et al., 2014). Net $\mathrm{N}$ mineralization was calculated as the difference between total inorganic $\mathrm{N}$ concentration $\left(\mathrm{NO}_{3}^{-}-\mathrm{N}\right.$ and $\left.\mathrm{NH}_{4}^{+}-\mathrm{N}\right)$ before and after incubation (Song et al., 2011).

We calculated the net soil $\mathrm{C}$ balance of the soil $\left(\mathrm{C}_{\text {balance }}\right)$ as: $\mathrm{C}_{\text {balance }}=$ $\left(C_{i}-C_{\mathrm{CO} 2}\right) / C_{\text {soil }}$, where $C_{\text {soil }}$ is the $C$ pool of the soil, $C_{i}$ is the $C$ pool of the soil or soil and litter, and $\mathrm{C}_{\mathrm{CO} 2}$ is $\mathrm{CO}_{2}-\mathrm{C}$ emitted from the soil or from both soil and litter.

\subsection{Statistical analyses}

We used two-way ANOVA to examine the effects of water treatment and litter addition on $\mathrm{C}$ mineralization, net $\mathrm{N}$ mineralization, $\mathrm{MBC}, \mathrm{MBN}$, and net $\mathrm{C}$ balance. Tukey HSD tests were used for multiple comparisons. Regression analysis was used to test relationships among $C$ mineralization, net $\mathrm{N}$ mineralization, $\mathrm{MBC}$ and $\mathrm{MBN}$. This analysis was done for all the treatments combined and also separately for the treatments with and without litter addition. If significant relationships were detected for treatments both with and without litter addition, we use ANCOVA to compare whether the slops of the regressions differed significantly between treatments with and without litter addition. All the statistical analyses were conducted using SPSS 18.0 (SPSS, Chicago, IL, USA) and the effects were considered significant if $P<0.05$.

\section{Results}

3.1. Effects of water treatment and litter addition on cumulative $\mathrm{CO}_{2}$ emissions and net $N$ mineralization

There were significant effects of litter addition, water treatment, and their interactions on cumulative $\mathrm{CO}_{2}$ emission and net $\mathrm{N}$ mineralization (Table 1). Litter addition significantly increased cumulative $\mathrm{CO}_{2}$ emission (Fig. 2A). Cumulative $\mathrm{CO}_{2}$ emission was significantly lower in the wet treatment than in the dry and the drying-rewetting treatment (Fig. 2A). Without litter addition, cumulative $\mathrm{CO}_{2}$ emission was significantly greater in the drying-rewetting treatment than in the dry treatment, but with litter addition it was smaller (Fig. 2A).

Litter addition significantly decreased net $\mathrm{N}$ mineralization, and net $\mathrm{N}$ mineralization was significantly lower in the drying-rewetting treatment than in the wet treatment (Fig. 2B). Without litter addition, net $\mathrm{N}$ mineralization was significantly smaller in the drying-rewetting treatment than in the dry treatment (Fig. 2B), but with litter addition it was markedly larger (Fig. 2B).

\subsection{Effects of water treatment and litter addition on $M B C$ and $M B N$}

There were significant main effects of litter addition and water treatment on MBC (Table 1). Litter addition significantly increased MBC (Fig. 3A). Without litter addition, MBC was significantly smaller in the dry treatment than in the wet and drying-rewetting treatments, but with litter addition it did not differ significantly among the three water treatments (Fig. 3A).

Litter addition, water treatment and their interactions significantly affected MBN (Table 1). Litter addition significantly increased MBN (Fig. 3B). Without litter addition, MBN was significantly smaller in the drying-rewetting and wet treatments than in the dry treatment, but with litter addition it was the highest in the dry treatment, lowest in the wet treatment, and intermediate in the drying-rewetting treatment (Fig. 3B).

\subsection{Relationships among $\mathrm{CO}_{2}$ emission, $\mathrm{N}$ mineralization, $\mathrm{MBC}$, and $\mathrm{MBN}$}

Cumulative $\mathrm{CO}_{2}$ emission was significantly negatively related to net $\mathrm{N}$ mineralization in treatments both with and without litter addition, but litter addition enhanced the negative relationship (i.e. the slope was steeper; ANCOVA: $F=263.2, P<0.001$; Fig. 4). Furthermore, with litter addition, high $\mathrm{C}$ mineralization was associated with high net $\mathrm{N}$ immobilization in the dry treatment, and low $\mathrm{C}$ mineralization was associated with low net $\mathrm{N}$ immobilization in the wet treatment.

Across the two litter addition treatments, both MBC and MBN were significantly positively related to $C$ mineralization, but negatively related to net $\mathrm{N}$ mineralization (Fig. 5). With litter addition, MBN was significantly positively related to $\mathrm{C}$ mineralization, and negatively related to net $\mathrm{N}$ mineralization (Appendix Table 1 ). Without litter addition, however, neither MBC nor MBN was significantly related to $C$ mineralization or net $\mathrm{N}$ mineralization (Appendix Table 1).
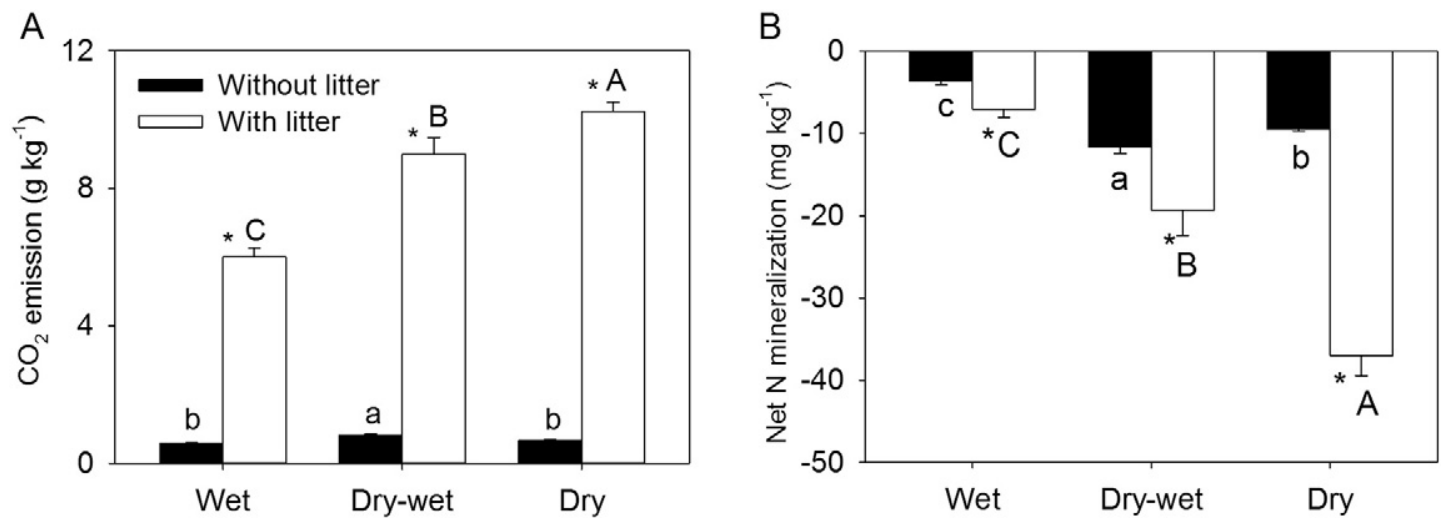

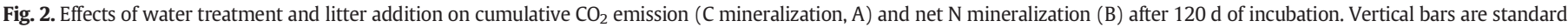

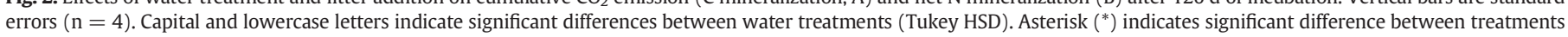
with and without litter ( $t$-test). 


\subsection{Net soil C balance}

Net soil C balance was positive in the treatments with litter addition and negative in the treatments without litter addition (Fig. 6). Litter addition $\left(\mathrm{F}_{1,18}=227.7, P<0.001\right)$, water treatment $\left(\mathrm{F}_{2,18}=5.3, P=\right.$ $0.016)$, and their interaction $\left(F_{2,18}=13.7, P<0.001\right)$ significantly affected net soil $C$ balance. With litter addition, net soil $C$ balance was the highest in the wet treatment, lowest in the dry treatment, and in between in the drying-rewetting treatment; without litter addition it was significantly higher in the drying-rewetting treatment than in the wet and dry treatments (Fig. 6).

\section{Discussion}

Effects of drying-rewetting cycles on SOC decomposition have been extensively investigated under both laboratory and field conditions (e.g., Borken and Matzner, 2009; Moyano et al., 2013; Zhu and Cheng, 2013; Morillas et al., 2015). Numerous studies have suggested that drying-rewetting cycles enhance soil respiration (Borken and Matzner, 2009; Moyano et al., 2013; Morillas et al., 2015), while other studies have shown no change or even a decrease in cumulative $\mathrm{C}$ mineralization compared to constant soil moisture (Mikha et al., 2005; Muhr et al., 2010). One possible explanation for enhancement of soil respiration by drying-rewetting cycles is that dead microorganisms release intra-cellular osmolytes due to the change in water pressure, fracture of soil aggregates, and uncoupling of enzymatic activity from cellular respiration during drying-rewetting cycles (Moyano et al., 2013; Morillas et al., 2015). As a result, the sequence of drying and rewetting makes substrate available for microorganisms. In this study, we found that drying-rewetting cycles significantly accelerated C mineralization, supporting our hypothesis that drying-rewetting cycles have potential to modify SOC dynamics and accelerate $\mathrm{CO}_{2}$ emissions compared to saturated moisture conditions in alpine wetlands.

$\mathrm{C}$ mineralization can be altered by litter addition because substrate quality is more important than temperature and soil moisture (Chen et al., 2015; He et al., 2014). Litter often serves as an easily degradable labile C pool for microbial growth (Benesch et al., 2015). In this alpine wetland soil, $\mathrm{C}$ mineralization could be limited by $\mathrm{C}$ availability due to low C/N (12.6 \pm 1.3$)$ despite high $\mathrm{C}$ content. Therefore, litter addition accelerated $\mathrm{CO}_{2}$ emission, but the quantity of emission was regulated by soil moisture (Fig. 6 ). Without litter addition, net soil $\mathrm{C}$ balance was negative, which was further intensified by drying-rewetting cycles (Fig. 6). With litter addition, soil net $\mathrm{C}$ balance was positive due to a fraction of the litter remaining in the soil and compensating for the $\mathrm{C}$ loss via mineralization. Compared to saturated soil, drying-rewetting cycles reduced net $\mathrm{C}$ increase due to increased decomposition. These findings

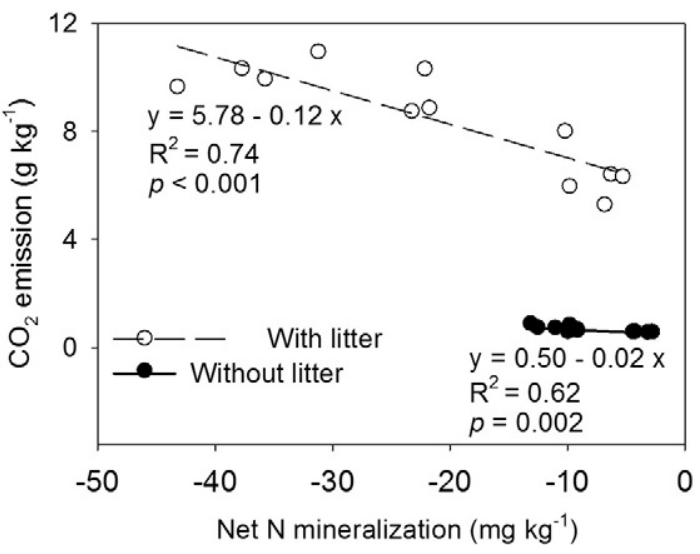

Fig. 4. Relationships between cumulative $\mathrm{CO}_{2}$ emission ( $\mathrm{C}$ mineralization) and net $\mathrm{N}$ mineralization in alpine wetland soils incubated with and without litter addition.

indicate that future climate change on the Tibetan Plateau, including change in temperature and precipitation, has potential to affect both litter and SOC decomposition and net soil $\mathrm{C}$ balance in alpine wetlands.

As previously expected, $\mathrm{N}$ mineralization was dominated by $\mathrm{N}$ immobilization in all treatments. Drying-rewetting cycles significantly enhanced $\mathrm{N}$ immobilization compared to saturated conditions, mainly because drying-rewetting cycles can make substrate available for microorganisms (He et al., 2014). Nitrogen immobilization was greatly increased with litter addition, which is accordance with other studies on Arctic (Jonasson et al., 2006) or alpine meadow soils (He et al., 2014). Microorganisms were activated and grew due to litter addition, consequently requiring more available nutrients, as shown by increased MBN and MBC (Fig. 3). Compared to soils and microbial biomass, a high $\mathrm{C} / \mathrm{N}$ ratio of litter indicates high $\mathrm{N}$ requirement for microorganisms, and this results in high $\mathrm{N}$ immobilization during litter decomposition (Craine et al., 2007; He et al., 2014). N immobilization was high in the $60 \%$ WHC treatment (Fig. 2), probably due to the high $\mathrm{N}$ requirement for microorganisms at this suitable soil moisture. This confirms our hypothesis that litter can increase microbial $\mathrm{N}$ immobilization, but that this process can be modulated by soil moistures.

Both MBC and MBN were significantly positively correlated with $C$ mineralization and negatively with $\mathrm{N}$ mineralization (Fig. 5). A possible reason is that soil microorganisms were $\mathrm{N}$-limited in alpine wetlands. Consumption of labile $\mathrm{C}$ from litter leads to an increased microbial demand for $\mathrm{N}$ and facilitates microbial $\mathrm{N}$ retention (Schaeffer and Evans, 2005). As has been found in other alpine meadow soils (Song et al.,
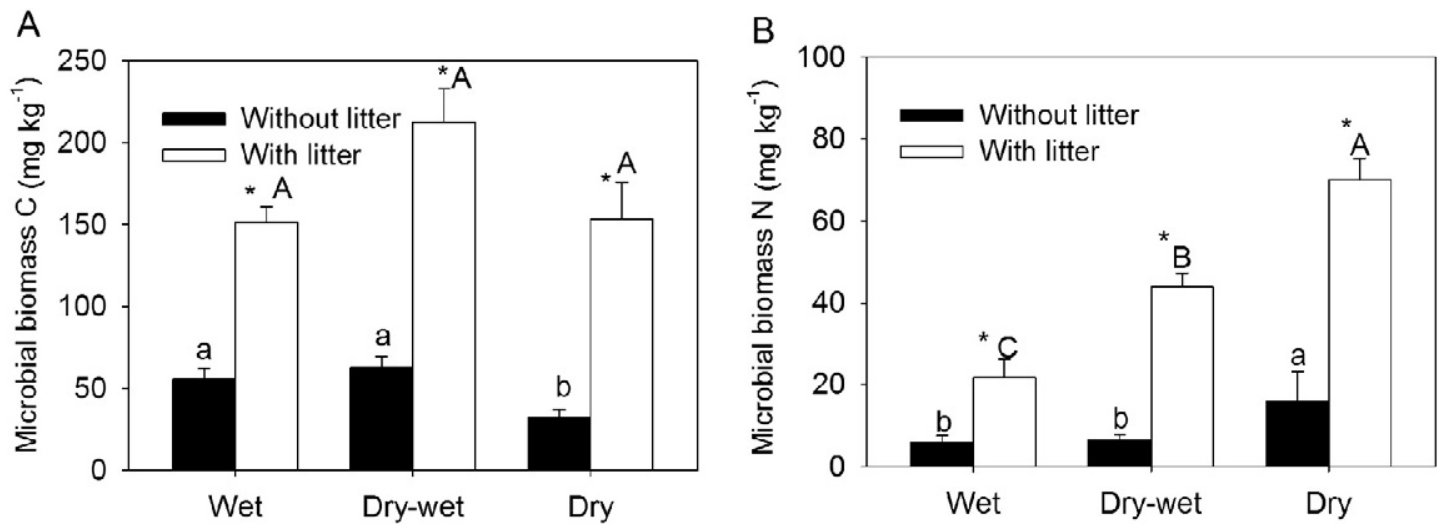

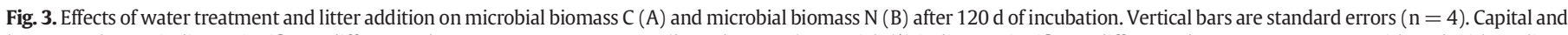

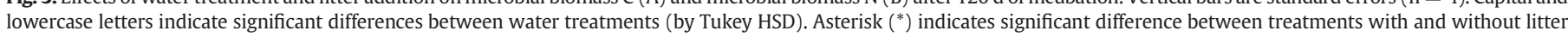
( $t$-test). 
A

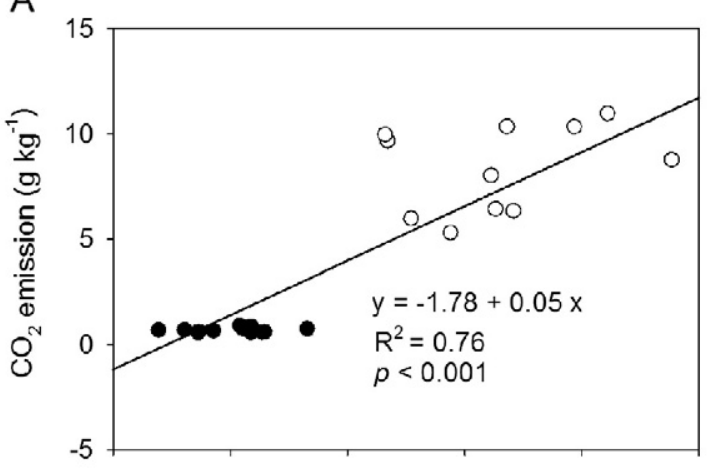

C

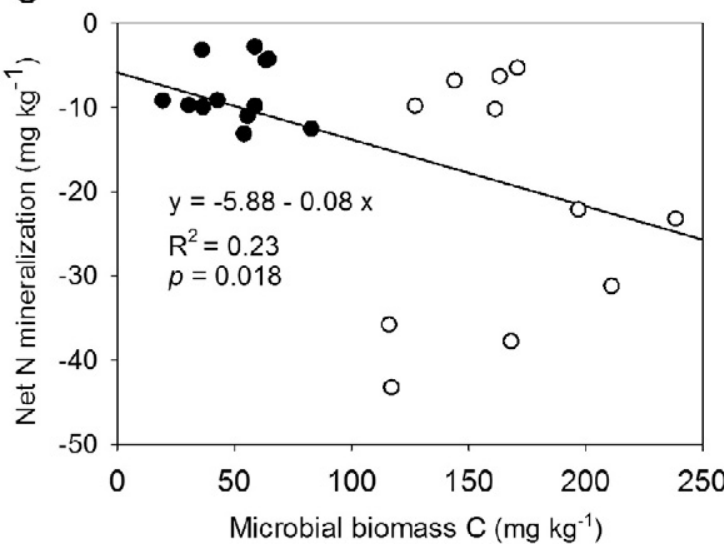

B

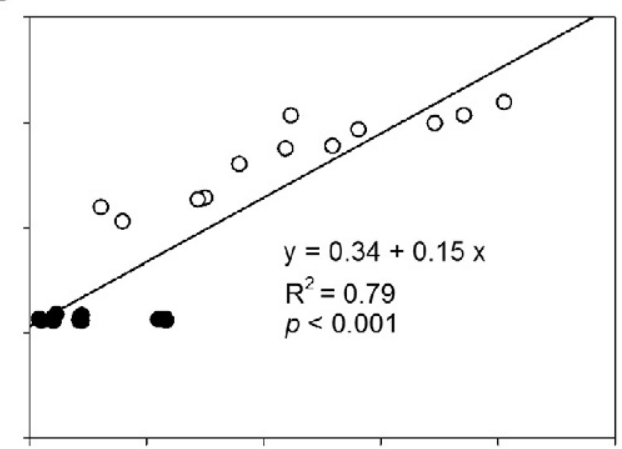

D

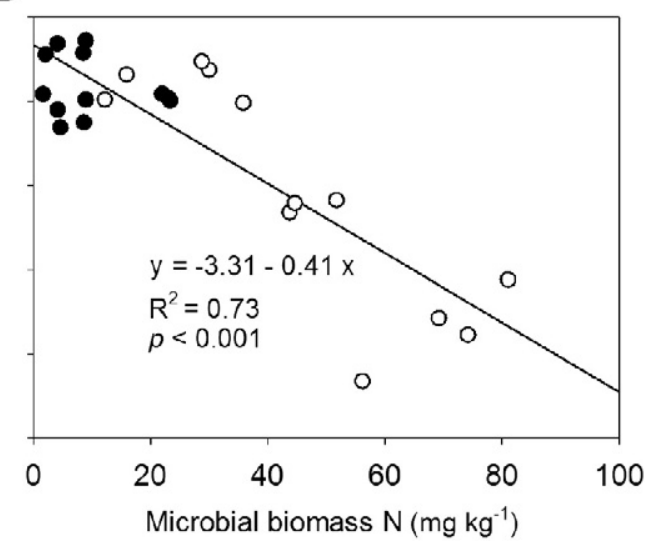

Fig. 5. Relationships between microbial biomass $C(M B C)$ and $N(M B N)$, and $C$ and net $N$ mineralization in alpine wetland soils incubated with and without litter.

2010; He et al., 2014), we found that $C$ and $N$ mineralization became more coupled when litter was added in the alpine wetland soil (Fig. 4). These findings indicate that the availability of substrates such as litter can modify the coupling of $\mathrm{C}$ and $\mathrm{N}$ cycling in alpine wetlands through affecting microbial activity.

We conclude that litter can enhance $\mathrm{C}$ mineralization and $\mathrm{N}$ immobilization in alpine wetland soils through effects on microbial biomass and lead to greater $\mathrm{N}$-limitation of plant growth. Our results also suggest that such an effect of litter could be modulated by changes in soil moisture due to climate change.

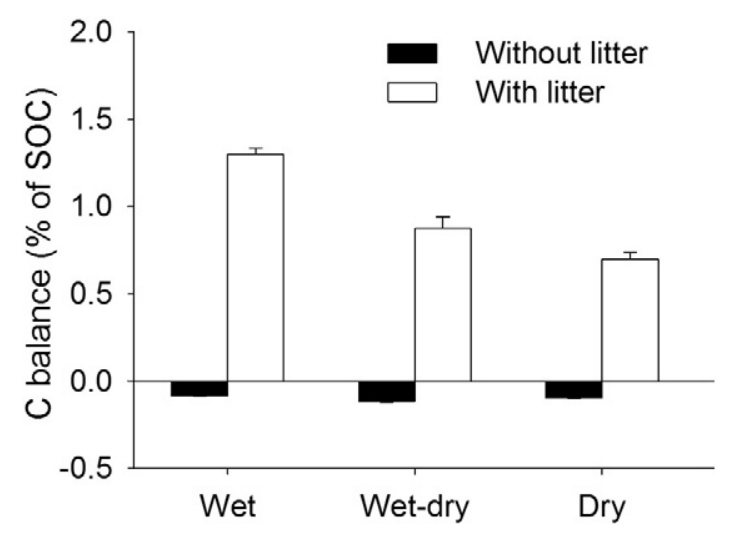

Fig. 6. Effects of water and litter on net $\mathrm{C}$ balance of soil samples after $120 \mathrm{~d}$ of incubation. Vertical bars are standard errors $(n=4)$. Capital and lowercase letters indicate significant differences between water treatments (Tukey HSD). Asterisk $\left({ }^{*}\right)$ indicates significant difference between with and without litter ( $t$-test).

\section{Acknowledgements}

We thank Ms. Bo-Ya Zhang for help with lab work, and the two anonymous reviewers for their helpful comments on the manuscript. This work was supported by the Fundamental Research Funds for the Central Universities (TD-JC-2013-1) and the National Natural Science Foundation of China (41571084 and 41071329).

\section{Appendix A. Appendix}

Appendix Table 1

Linear regression analyses of microbial biomass $\mathrm{C}(\mathrm{MBC})$ and $\mathrm{N}(\mathrm{MBN})$ on $\mathrm{C}$ and net $\mathrm{N}$ mineralization in alpine wetland soils incubated with and without litter.

\begin{tabular}{|c|c|c|c|c|c|c|c|c|}
\hline & \multicolumn{4}{|l|}{ MBC } & \multicolumn{4}{|l|}{ MBN } \\
\hline & Slope & Intercept & $\mathrm{R}^{2}$ & $P$ & Slope & Intercept & $\mathrm{R}^{2}$ & $P$ \\
\hline \multicolumn{9}{|c|}{$\mathrm{CO}_{2}$ emission } \\
\hline $\begin{array}{l}\text { Without } \\
\text { litter }\end{array}$ & 0.001 & 0.63 & 0.04 & 0.538 & -0.002 & 0.71 & 0.03 & 0.597 \\
\hline $\begin{array}{l}\text { With } \\
\text { litter }\end{array}$ & 0.012 & 6.35 & 0.08 & 0.388 & 0.081 & 4.73 & 0.85 & $<\mathbf{0 . 0 0 1}$ \\
\hline \multicolumn{9}{|c|}{$\mathrm{N}$ mineralization } \\
\hline $\begin{array}{c}\text { Without } \\
\text { litter }\end{array}$ & -0.005 & -8.04 & 0.001 & 0.944 & -0.092 & -7.36 & 0.04 & 0.520 \\
\hline $\begin{array}{l}\text { With } \\
\text { litter }\end{array}$ & 0.014 & -23.57 & 0.002 & 0.884 & -0.521 & 2.47 & 0.73 & $<\mathbf{0 . 0 0 1}$ \\
\hline
\end{tabular}

$P$ values less than 0.05 are in bold.

\section{References}

Ataka, M., Kominami, Y., Yoshimura, K., Miyama, T., Jomura, M., Tani, M., 2014. In situ $\mathrm{CO}_{2}$ efflux from leaf litter layer showed large temporal variation induced by rapid wetting and drying cycle. PLoS One 9, e108404. http://dx.doi.org/10.1371/journal.pone. 0108404. 
Benesch, M., Glaser, B., Dippold, M., Zech, W., 2015. Soil microbial C and N turnover under Cupressus lusitanica and natural forests in southern Ethiopia assessed by decomposition of ${ }^{13} \mathrm{C}$ - and ${ }^{15} \mathrm{~N}$-labelled litter under field conditions. Plant Soil 388, 133-146.

Bengtson, P., Barker, J., Grayston, S.J., 2012. Evidence of a strong coupling between root exudation, $\mathrm{C}$ and $\mathrm{N}$ availability, and stimulated SOM decomposition caused by rhizosphere priming effects. Ecol. Evol. 2, 1843-1852.

Bernal, B., Mitsch, W.J., 2013. Carbon sequestration in freshwater wetlands in Costa Rica and Botswana. Biogeochem. 115, 77-93.

Blake, G., Hartge, K., 1986. Bulk density. In: Klute, A. (Ed.), Methods of Soil Analysis. Part 1. Physical and Mineralogical Methods, 2nd (Eds.), pp. 363-382 ASA - SSSA No. 9, Madison, Wisconsin, USA.

Borken, W., Matzner, E., 2009. Reappraisal of drying and wetting effects on C and N mineralization and fluxes in soils. Glob. Chang. Biol. 15, 808-824.

Brookes, P., Landman, A., Pruden, G., Jenkinson, D., 1985. Chloroform fumigation and the release of soil nitrogen-a rapid direct extraction method to measure microbial biomass nitrogen in soil. Soil Biol. Biochem. 17, 837-842.

Chai, X., Lang, H., Jin, S., Zu, W., Ma, X., Zhang, Z., 1965. Marshes on Zoigê Plateau. Science Press, Beijing, China.

Chen, S., Wang, Y., Hu, Z., Gao, H., 2015. $\mathrm{CO}_{2}$ emissions from a forest soil as influenced by amendments of different crop straws: implications for priming effects. Catena 131, 56-63.

Craine, J.M., Morrow, C., Fierer, N., 2007. Microbial nitrogen limitation increases decomposition. Ecology 88, 2105-2113.

Dijkstra, F.A., Cheng, W., 2007. Interactions between soil and tree roots accelerate longterm soil carbon decomposition. Ecol. Lett. 10, 1046-1053.

Ding, W., Cai, Z., Wang, D., 2004. Preliminary budget of methane emissions from natural wetlands in China. Atmos. Environ. 38, 751-759.

Fierer, N., Schimel, J.P., 2002. Effects of drying-rewetting frequency on soil carbon and nitrogen transformations. Soil Biol. Biochem. 34, 777-787.

He, Y., Xu, X., Kueffer, C., Zhang, X., Shi, P., 2014. Leaf litter of a dominant cushion plant shifts nitrogen mineralization to immobilization at high but not low temperature in an alpine meadow. Plant Soil 383, 415-426.

Huntington, T.G., 2006. Evidence for intensification of the global water cycle: review and synthesis. J. Hydrol. 319, 83-95.

Huxman, T., Smith, M., Fay, P., 2004. Convergence across biomes to a common rain-use efficiency. Nature 429, 651-654.

Inglima, I., Alberti, G., Bertolini, T., Vaccari, F.P., Gioli, B., Miglietta, F., Cotrufo, M.F. Peressotti, A., 2009. Precipitation pulses enhance respiration of Mediterranean ecosystems: the balance between organic and inorganic components of increased soil $\mathrm{CO}_{2}$ efflux. Glob. Chang. Biol. 15, 1289-1301.

IPCC, 2013. Climate Change 2013: The Physical Science Basis.

Jarvis, P., Rey, A., Petsikos, C., Wingate, L., Rayment, M., Pereira, J., Banza, J., David, J., Miglietta, F., Borghetti, M., Manca, G., Valentini, R., 2007. Drying and wetting of Mediterranean soils stimulates decomposition and carbon dioxide emission: the "Birch effect". Tree Physiol. 27, 929-940.

Jonasson, S., Castro, J., Michelsen, A., 2006. Interactions between plants, litter and microbes in cycling of nitrogen and phosphorus in the arctic. Soil Biol. Biochem. 38, $526-532$.

Liao, J., 2013. Dry/wet variations in Zoige wetland based on Z index. Journal of Changchun Normal University (Natural Science) 32, 83-86.
Mikha, M.M., Rice, C.W., Milliken, G.A., 2005. Carbon and nitrogen mineralization as affected by drying and wetting cycles. Soil Biol. Biochem. 37, 339-347.

Mitsch, W., Gosselink, J., 2007. Wetlands. John Wiley \& Sons, Inc., Hoboken, New Jersey.

Morillas, L., Duran, J., Rodriguez, A., Roales, J., Gallardo, A., Lovett, G.M., Groffman, P.M., 2015. Nitrogen supply modulates the effect of changes in drying-rewetting frequency on soil C and N cycling and greenhouse gas exchange. Glob. Chang. Biol. 21, 3854-3863.

Moyano, F.E., Manzoni, S., Chenu, C. 2013 Responses of soil heterotrophic respiration to moisture availability: an exploration of processes and models. Soil Biol. Biochem. 59, $72-85$.

Muhr, J., Franke, J., Borken, W., 2010. Drying-rewetting events reduce C and N losses from a Norway spruce forest floor. Soil Biol. Biochem. 42, 1303-1312.

Prieme, A., Christensen, S., 2001. Natural perturbations, drying-wetting and freezingthawing cycles, and the emission of nitrous oxide, carbon dioxide and methane from farmed organic soils. Soil Biol. Biochem. 33, 2083-2091.

Reichstein, M., Bahn, M., Ciais, P., Frank, D., Mahecha, M.D., Seneviratne, S.I., Zscheischler J., Beer, C., Buchmann, N., Frank, D.C., Papale, D., Rammig, A., Smith, P., Thonicke, K. Van Der Velde, M., Vicca, S., Walz, A., Wattenbach, M., 2013. Climate extremes and the carbon cycle. Nature 500, 287-295.

Rey, A., Petsikos, C., Jarvis, P.G., Grace, J., 2005. Effect of temperature and moisture on rates of carbon mineralization in a Mediterranean oak forest soil under controlled and field conditions. Eur. J. Soil Sci. 56, 589-599.

Schaeffer, S.M., Evans, R.D., 2005. Pulse additions of soil carbon and nitrogen affect soil nitrogen dynamics in an arid Colorado Plateau shrubland. Oecologia 145, 425-433.

Seneviratne, S.I., Corti, T., Davin, E.L., Hirschi, M., Jaeger, E.B., Lehner, I., Orlowsky, B., Teuling, A.J., 2010. Investigating soil moisture-climate interactions in a changing climate: a review. Earth Sci. Rev. 99, 125-161.

Song, M., Jiang, J., Cao, G., Xu, X., 2010. Effects of temperature, glucose and inorganic nitrogen inputs on carbon mineralization in a Tibetan alpine meadow soil. Eur. J. Soil Biol. 46, 375-380.

Song, M., Jiang, J., Xu, X., Shi, P., 2011. Correlation between $\mathrm{CO}_{2}$ efflux and net nitrogen mineralization and its response to external $\mathrm{C}$ or $\mathrm{N}$ supply in an alpine meadow soil. Pedosphere 21, 666-675.

WRB, 2014. World Reference Base for Soil Resources 2014. International Soil Classification System for Naming Soils and Creating Legends for Soil Maps. FAO, Rome.

Wu, J., Joergensen, R., Pommerening, B., Chaussod, R., Brookes, P. 1990. Measurement of soil microbial biomass $C$ by fumigation extraction - an automated procedure. Soil Biol. Biochem. 22, 1167-1169.

Xing, Y., Jiang, Q., Li, W., Bai, L., 2009. Landscape spatial patterns changes of the wetland in Qinghai-Tibet Plateau. Ecol. Envir. Sci. 18, 1010-1015.

Yu, F., Li, P., Li, S., He, W., 2010. Kobresia tibetica tussocks facilitate plant species inside them and increase diversity and reproduction. Basic Appl. Ecol. 11, 743-751.

Zhang, Y., Wang, G., Wang, Y., 2011. Changes in alpine wetland ecosystems of the Qinghai-Tibetan plateau from 1967 to 2004. Environ. Monit. Assess. 180 (1-4), 189-199.

Zhu, B., Cheng, W., 2013. Impacts of drying-wetting cycles on rhizosphere respiration and soil organic matter decomposition. Soil Biol. Biochem. 63, 89-96. 